\title{
Antimicrobial Susceptibility of Bacteria Detected from the Root Canal Infection (Before and After) Root-Filled Teeth: An in Vitro Study
}

\author{
Gamal M. EL-Sherbiny* \\ Assistant professor Botany and Microbiology Department, Faculty of Science, Al- Azhar University, Cairo, Egypt \\ *Corresponding author: gamalelsherbiny1970@yahoo.com
}

Received December 02, 2014; Revised December 17, 2014; Accepted January 04, 2015

\begin{abstract}
The aim of the study was to investigate the bacterial species from root canal infection (before and after) filled teeth and evaluate susceptibility to antibiotics, antimicrobial agents and plant extracted from ginger (Zingiber officinale).Thirty-three adult patients with symptoms of root canal infection was receiving at the outpatient clinic, Faculty of Dental Medicine, Al-Azhar University, Cairo, Egypt, 2014, diagnosed by a physician participated in the study. Forty- five bacterial samples were taken from root canals infection, 33 before and 12 after filled teeth. A total 126 bacterial isolates were isolated and identify from this samples. The predominant bacterial isolates were found Enterococcus faecalis 15\%, followed by Streptococcus mutans 9.5\%, Streptococcus acidominimus $8.7 \%$ and Porphyromonas gingivalis $7.93 \%$. The bacterial isolates highly sensitive to amoxicillin-clavulanic acid, vancomycin and erythromycin. About $36.50 \%$ of the isolates were resistant to tetracycline. More than $50 \%$ of all isolates were resistant to metronidazole. The sensitivity of bacterial isolates to antimicrobial agents revealed that sensitive $87.30 \%$ to potassium iodide $2.0 \%, 73.01 \%$ to calcium hydroxide $2 \%, 69 \%$ to chlorxidine $1 \%$ and $54 \%$ to sodium hypochlorite $0.5 \%$. The in vitro antibacterial activity of Zingiber officinale was studied against bacterial isolates. The aqueous and ethanolic extracts of Zingiber officinale exhibited antibacterial activity against all bacterial isolates with MIC ranged from 0.5 to $1.3 \mathrm{mg} / \mathrm{ml}$ and 0.3 to $1.0 \mathrm{mg} / \mathrm{ml}$ respectively. In conclusions, amoxicillin-clavulanic acid and vancomycin most potent antibiotics and potassium iodide $2 \%$ most antimicrobial agents against bacterial isolates. Zingiber officinale extract has potential antimicrobial action against bacterial isolates.
\end{abstract}

Keywords: root canal infection, bacterial sp., antimicrobial susceptibility and Zingiber officinale

Cite This Article: Gamal M. EL-Sherbiny, "Antimicrobial Susceptibility of Bacteria Detected from the Root Canal Infection (Before and After) Root-Filled Teeth: An in Vitro Study.” International Journal of Dental Sciences and Research, vol. 3, no. 1 (2015): 4-9. doi: 10.12691/ijdsr-3-1-2.

\section{Introduction}

Oral diseases like dental caries, periodontitis, oral tissue lesions, infections and oral cavity cancers are major health problems worldwide [1]. Oral health influences general quality of life and poor oral health is linked to systemic conditions. In some countries dental diseases are the fourth most expensive diseases to treat. The oral cavity is colonized by 750 species of microbes and a number of these are implicated in oral diseases. [2]. Endodontic is largely concerned with the treatment of infections originating in the root canal system. Microorganisms are the primary etiological agent for the root canal system infections and periapical lesions [2,4]. Endodontic infections are polymicrobial involving a combination of Gram-positive, Gram-negative, facultative anaerobes and strict anaerobic bacteria [5]. The bacteria remaining in the root canal system after endodontic treatment cause secondary, or persistent, infections [6]. Although more than 300 species of bacteria have been isolated from the oral cavity, only a limited number have been consistently isolated from endodontic infections [7]. These include species of the genera Streptococcus, Fusobacterium, Prevo-tella, Porphyromonas, Eubacterium, Peptostreptococcus, Bacteroides, and Lactobacillus [7,8]. Baumgartner and Falkler 1991 found that Actinomyces species were amongst the most prominent bacteria cultured from the 10 root canals examined [9]. Hancock et al., 2001 examined root filled teeth with persistent periapical radiolucencies, and found that as well as Enterococcus, other genera, viz. Peptostreptococcus, Actinomyces, and Streptococcus, predominated [10]. Additionally, Enterococcus has been isolated from $47 \%$ of root canals in which treatment had failed [11]. The role of systemic antibiotic therapy in endodontics is limited. Usually, it is applied when patients present with progressive, diffuse swelling and systemic signs of infection including fever, malaise, and lymphadenopathy. Systemic antibiotics may also be used as a prophylactic measure for medically compromised patients. The resistance of oral microflora to antibiotics has increased during the past decades, possibly because of 
the empiric use of antibiotics for a variety of pathologies [12]. Generally, facultative anaerobes are less susceptible to anti-microbial measures than are anaerobes and are therefore more likely to survive root canal treatment unless cleaning and shaping procedures are of the highest standard. The treatment resistance of enterococci in the root canal has long been recognized [13]. Significantly, calcium hydroxide has been shown to be ineffective in killing E. faecalis in root canals [14] and this is predictable because this microorganism is able to grow at high $\mathrm{pH}$ [15]. Sodium hypochlorite is also effective in aiding the mechanical flushing of debris from root canals. McComb and Smith 1975 showed that irrigation with 6\% sodium hypochlorite resulted in canals that were almost completely free of debris[16]. This compound dissolves organic matter [16] and has a broad spectrum of antimicrobial activity. Thus, sodium hypochlorite effectively eliminates microbes from root canals [18] and also kills bacteria within open dentinal tubules [19]. Potassium iodide (KI) root canal disinfectant when used as $2 \%$ solution, has acceptable antimicrobial properties, more pleasant odor, taste and lower toxicity when compared with sodium hypochlorite [20,21,22]. Safavi et al. demonstrated the efficacy of KI irrigant in eliminating E. faecalis when used for 10 minute in infected dentinal tubules following sodium hypochlorite irrigation [23]. Chlorhexidine is the most frequently widely used antimicrobial agents for treatment of root canal infection [24]. The plant is reported to have antibacterial, anti-oxidant, antiprotozoal, anti-fungal, anti-emetic, anti-rhinoviral, anti-inflammatory, anti-insecticidal activity. Reported pharmacological activities of Zingiber officinale include antipyretic, analgesic and antibacterial in addition to hypersensitive effects [25]. Thus, the aim of this study was to evaluate, in vitro, antimicrobial susceptibility to (antibiotics, sodium hypochlorite, calcium hydroxide and potassium iodide, chlorhexidine and Zingiber officinale) and viability of some endodontic organisms associated with refractory root canal infections.

\section{Material and Methods}

\subsection{Patient Selection}

Thirty-three adult patients with symptoms of root canal infection was receiving at the outpatient clinic, Faculty of Dental Medicine, Al-Azhar University, Cairo, Egypt, 2014, diagnosed by a physician participated in the study. Information about the patients' use of antimicrobial drugs was collected before the sampling procedure.

\subsection{Bacterial Sampling}

Bacterial samples were obtained from the root canal by using sterile paper points which introduced to the predetermined working length and held in place for 60 seconds to absorb the contents of the canal. Afterwards, the paper points were immediately transferred to Reduced Transport Fluid (RTF) media with aseptic precautions. Forty five samples were collected from patient, thirty three samples before treatment and twelve samples after treatment (filled teeth).

\subsection{Isolation and Characterization of Bacterial Species}

The samples were collected immediately streaked on (blood agar, chocolate agar, Brain Heart Infusion (BHI) and thioglyolate agar) and incubated aerobic and anaerobic by using anaerobic jars at $37^{\circ} \mathrm{C}$ for 24,48 and $72 \mathrm{~h}$. The bacterial isolates were identified using cultural, morphological, physiology and biochemical characteristics according to methods described by $[26,27,28]$.

\subsection{Antibiotics Susceptibility}

The antibiotic susceptibility of all bacterial isolates was measured. The following antibiotics were tested:

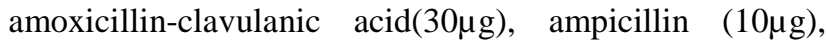
penicillin $(10 \mu \mathrm{g})$, metronidazole $(30 \mu \mathrm{g})$, tetracycline

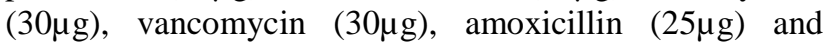
erythromycin $(10 \mu \mathrm{g})$. The antibiotics susceptibilities of the isolates were determined according to Clinical and Laboratory Standards Institute's guidelines National Committee for Clinical Laboratory Standards 2010 [29].

\subsection{Susceptibility of Bacterial Isolates to Antimicrobial Agents}

All isolates were also tested to determine susceptibility to antimicrobial agents including, $0.5 \%$ sodium hypochlorite, $2 \%$ potassium iodide, $2 \%$ calcium hydroxide, and $1 \%$ chlorhexidine by using agar dilution method. Growth meaning resistance and if there is no growth meaning sensitive.

\subsection{Zingiber officinale Extracts}

Ginger (Zingiber officinale) used in the present study were purchased from the local market of Cairo Egypt. Two types of extracts such as aqueous and ethanol extract from ginger were prepared separately. The fresh ginger rhizomes were washed, peeled, sliced and sun dried for seven days. After drying ginger slices were ground to fine powder separately using electric blender. $10 \mathrm{~g}$ powder of ginger was soaked in $100 \mathrm{ml}$ of distilled water and ethanol separately. The flasks were incubated at room temperature for 72 hours with shaking at $120 \mathrm{rpm}$. The crude extracts were centrifuged at $3000 \mathrm{rpm}$ for 10 minutes at $25^{\circ} \mathrm{C}$. The ethanol extracts was evaporated at $50^{\circ} \mathrm{C}$ while the aqueous extracts were evaporated at $80^{\circ} \mathrm{C}$ in rotary evaporator. All dried extract samples were dissolved in distilled water separately to the final concentration of $80 \mathrm{mg} / \mathrm{ml}$ and centrifuged again at10,000 rpm to remove the undissolved residues. The extract solutions were stored at $4^{\circ} \mathrm{C}$. The controls ethanol and water were treated in similar fashion as described for extract preparation and checked for antimicrobial activity.

\subsection{Antimicrobial Assay of Zingiber officinale}

The antimicrobial assay was performed by disc diffusion method as described by Kirby-Bauer [30]. The (BHI) plates were inoculated separately with $10^{8} \mathrm{CFU}$ of each test bacterial isolates culture and evenly spread on entire surface of each plate. The sterile discs $(5 \mathrm{~mm}$ diameter) were dipped aseptically in different extracts for one minute and placed over nutrient agar plates seeded with bacterial culture. The plates were left at ambient temperature for 15 minutes and then incubated at $37^{\circ} \mathrm{C}$ for 16 hours and observed for zone of inhibition. The diameter of inhibition zones was measured in millimeters. 


\subsection{Determination of Minimum Inhibitory Concentration (MIC)}

The MIC of ginger extracts was determined by method described by Natta et al [31]. The extracts were diluted ranging from $2 \mathrm{mg} / \mathrm{ml}$ to $0.1 \mathrm{mg} / \mathrm{ml}$ and checked for MIC against bacterial isolates. Sterile discs were dipped in different dilutions of aqueous and ethanol extracts of ginger and placed over (BHI) agar plates seeded with $10^{8} \mathrm{CFU}$ of each bacterial culture separately. Plates were placed at $37^{\circ} \mathrm{C}$ for 16 hours. The zone of inhibition in each case was measured as the diameter of the clearing zones and results were recorded.

\subsection{Identification Tests for Active Compounds}

Different color reactions were carried out to detect the presence of certain chemical constituents or chemical group in the Zingiber officinale extract according to methods described by Jadon and Dixit [32].

\section{Results}

Forty five samples from root canal infection (33 before and 12 after) filled teeth were used in this study. A total 126 bacterial isolates were isolated from this samples (72 isolates before and 54 isolates after) filled teeth. The bacterial isolates were subject to scheme for characterization and identification according to morphological, physiology and biochemical tests. After identification, bacterial isolates were grouping as the following, Streptococci sp. 36 isolates $28.5 \%$ (22 isolates before and 14 after), Enterococcus faecalis 19 isolates 15\% (9 isolates before and 10 after), anaerobes 60 isolates 47.6 (32 isolates before and 28 after) and other this group 11 isolates $8.7 \%$ (9 isolate before and 2 after). From results identification of bacterial isolates were found the predominate isolates Enterococcus faecalis 15\% (frequency 9 isolates before and 10 after) filled teeth followed by Streptococcus mutans 9.5\% (7 isolates before and 5 after), Streptococcus acidominimus $8.7 \%$ (6 isolates before and 5 after) and Porphyromonas gingivalis 7.39 \% (5 isolates before and 5 after). Streptococcus salivarius, Staphylococcus haemolyticus, Bacillus subtilis, Actinomyces viscosus and Corynebacterium sp. were isolated from root canal infection before, but not isolated after filled teeth. Figure 1, Figure 2. The antibiotics susceptibility of bacterial isolates, shown that most potent antibiotics were found amoxicillin-clavulanic acid, vancomycin, erythromycin recorded effective against isolates 96\%, $94 \%$ and $56.13 \%$ respectively Table 1 . About $56.34 \%$ of the isolates were resistant to metronidazole, $36.50 \%$ to tetracycline, $34.50 \%$ to ampicillin, 32.53 to penicillin and $28.56 \%$ to amoxicillin. The sensitivity of bacterial isolates to antimicrobial agents summarized in Table 2 revealed that sensitive $87.30 \%$ from bacterial isolates to potassium iodide $2.0 \%, 73.01 \%$ calcium hydroxide $2 \%$, $69 \%$ to chlorxidine $1 \%$ and $54 \%$ to sodium hypochlorite $0.5 \%$ Table 2 . The in vitro antibacterial activity of the Zingiber officinale extract using the disk diffusion method was demonstrated that Zingiber officinale had most potent activity against bacterial sp. isolated from root canal infection. The results of MIC values are summarized in Figure 3 shown that MIC ranged from 0.3 to $1.0 \mathrm{mg} / \mathrm{ml}$ with alcohol extract and 0.5 to $1.3 \mathrm{mg} / \mathrm{ml}$ with aqueous extract. Phytochemical analysis of Zingiber officinale constituents revealed that having chemical compounds, saponin, alkaloids, terpenoid and flavonoids. The results of phytochemical analysis are summarized in Table 3.

Table 1. Susceptibility of bacterial isolates to antibiotics

\begin{tabular}{|c|c|c|c|c|c|c|}
\hline Antibiotics & & $\begin{array}{c}\text { Anaerobes } \\
\mathbf{N}=\mathbf{6 0} \\
\%\end{array}$ & $\begin{array}{c}\text { Streptococci } \\
\mathbf{N}=36 \\
\% \\
\end{array}$ & $\begin{array}{c}\text { Enterococci } \\
\mathbf{N}=19 \\
\% \\
\end{array}$ & $\begin{array}{c}\text { Other } \\
\mathbf{N}=11 \\
\%\end{array}$ & $\begin{array}{c}\text { Total } \\
\mathbf{N}=126 \\
\%\end{array}$ \\
\hline \multirow{3}{*}{ Penicillin } & $\mathrm{S}$ & 43.33 & 58.32 & 63.20 & 45.45 & 50.79 \\
\hline & $\mathrm{I}$ & 21.60 & 22.20 & 0.0 & 0.0 & 16.66 \\
\hline & $\mathrm{R}$ & 34.87 & 19.50 & 36.84 & 54.54 & 32.53 \\
\hline \multirow{3}{*}{ Amoxicillin } & $\mathrm{S}$ & 46.48 & 52.77 & 68.41 & 54.54 & 52.37 \\
\hline & $\mathrm{I}$ & 24.90 & 19.50 & 5.26 & 9.09 & 19.04 \\
\hline & $\mathrm{R}$ & 28.22 & 27.80 & 26.31 & 36.36 & 28.56 \\
\hline \multirow{3}{*}{ Ampicillin } & $\mathrm{S}$ & 38.20 & 47.21 & 63.20 & 45.45 & 45.23 \\
\hline & $\mathrm{I}$ & 20.0 & 30.55 & 10.53 & 0.0 & 19.84 \\
\hline & $\mathrm{R}$ & 41.85 & 22.22 & 26.31 & 54.54 & 34.91 \\
\hline \multirow{3}{*}{ Tetracycline } & $\mathrm{S}$ & 49.98 & 44.44 & 52.63 & 36.36 & 47.61 \\
\hline & $\mathrm{I}$ & 18.32 & 13.9 & 10.53 & 18.18 & 15.87 \\
\hline & $\mathrm{R}$ & 31.65 & 41.70 & 36.84 & 45.45 & 36.50 \\
\hline \multirow{2}{*}{ Amoxicillin-clavulanic acid } & $\mathrm{S}$ & 100 & 91.57 & 89.47 & 100 & 96.00 \\
\hline & $\mathrm{R}$ & 0.0 & 8.31 & 10.52 & 0.0 & 4.00 \\
\hline \multirow{2}{*}{ Vancomycin } & $\mathrm{S}$ & 100 & 88.64 & 89.47 & 90.91 & 94.43 \\
\hline & $\mathrm{R}$ & $\begin{array}{ll}--- \\
\end{array}$ & 11.08 & 10.52 & 9.09 & 5.55 \\
\hline \multirow{3}{*}{ Erythromycin } & $\mathrm{S}$ & 53.31 & 55.55 & 68.42 & 63.63 & 57.13 \\
\hline & $\mathrm{I}$ & 18.32 & 8.31 & 0.0 & 0.0 & 11.11 \\
\hline & $\mathrm{R}$ & 28.32 & 36.10 & 31.58 & 36.36 & 31.74 \\
\hline \multirow{3}{*}{ Metronidazole } & $\mathrm{S}$ & 68.10 & 0.0 & 0.0 & 0.0 & 32.53 \\
\hline & $\mathrm{I}$ & 8.30 & 13.90 & 10.53 & 18.18 & 11.11 \\
\hline & $\mathrm{R}$ & 23.33 & 86.09 & 89.48 & 81.82 & 56.34 \\
\hline
\end{tabular}




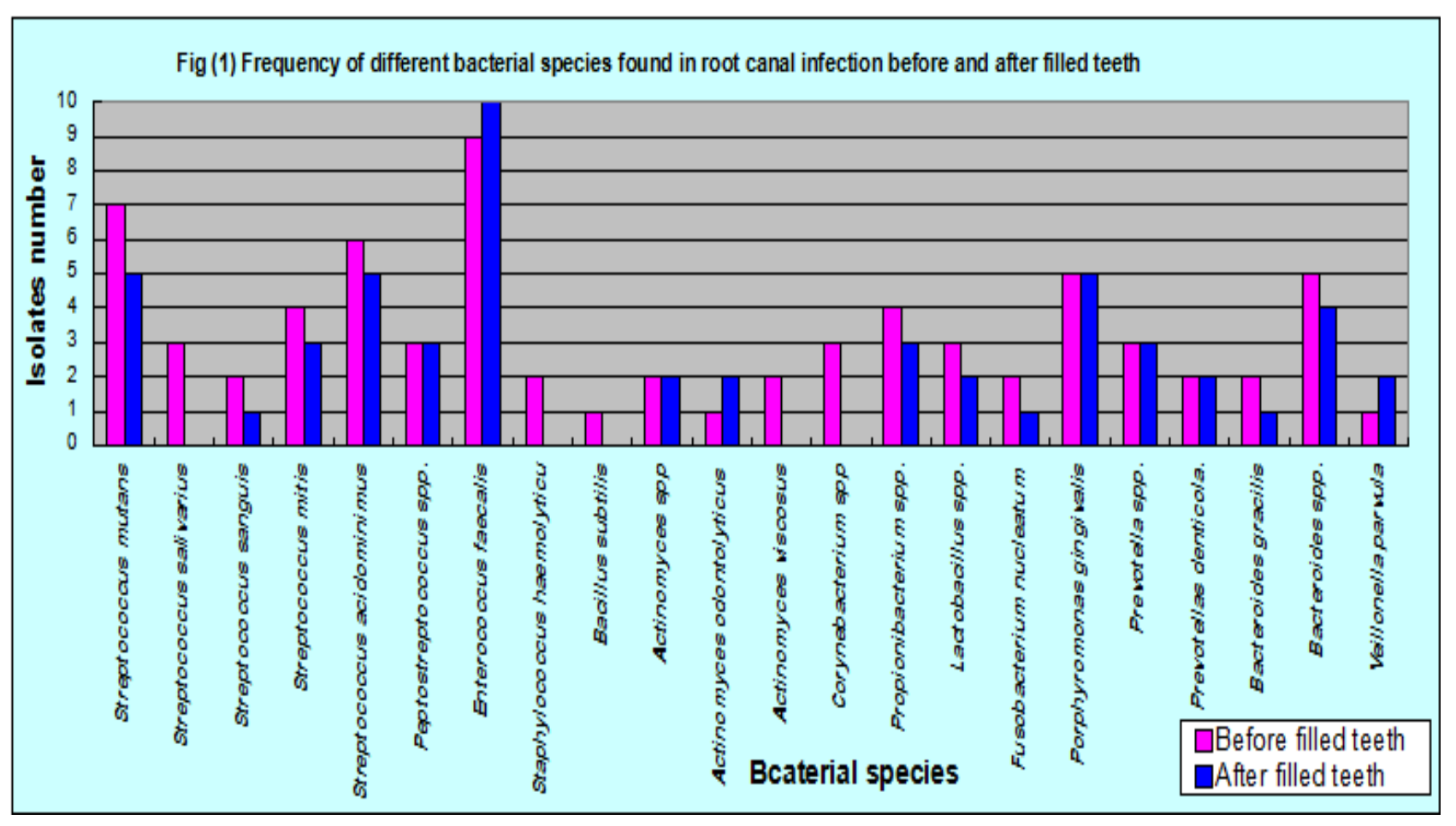

Figure 1. Frequency of different bacterial species found in root canal infection before and after filled teeth

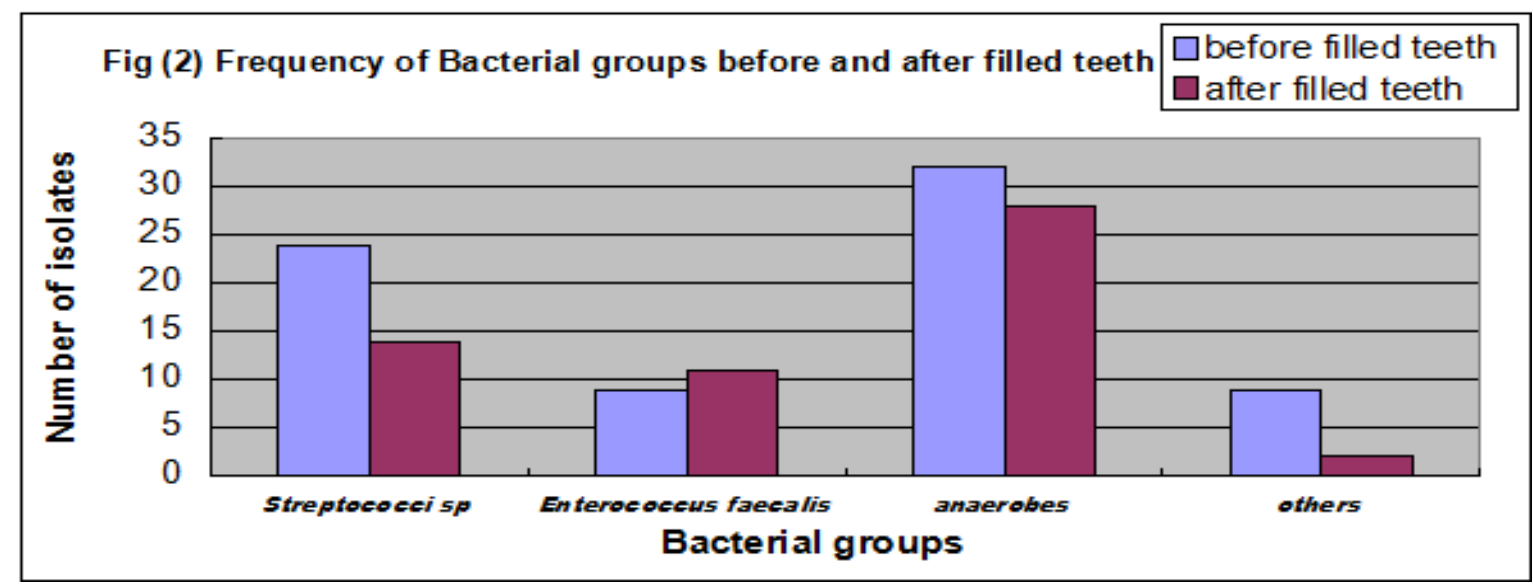

Figure 2. Frequency of Bacterial groups before and after filled teeth

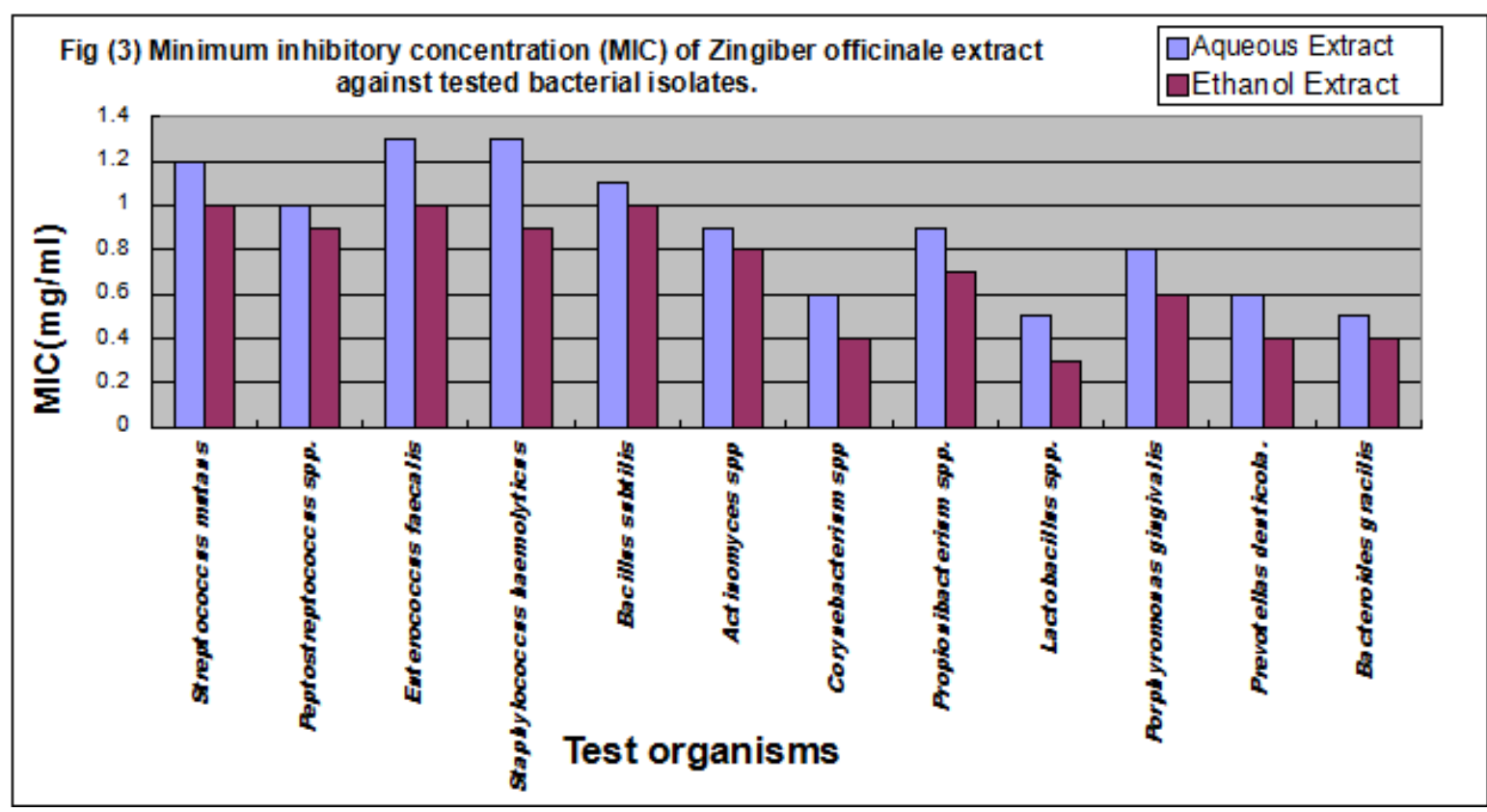

Figure 3. Minimum inhibitory concertration (MIC) of Zingiber officinale extract against tested bacterial isolates 
Table 2. Susceptibility of bacterial isolates to antimicrobial agents

\begin{tabular}{|c|c|c|c|c|c|c|}
\hline antimicrobial agents & & $\begin{array}{c}\text { Anaerobes } \\
\mathbf{N}=\mathbf{6 0} \\
\%\end{array}$ & $\begin{array}{c}\text { Streptococci } \\
\mathbf{N}=36 \\
\% \\
\end{array}$ & $\begin{array}{c}\text { Enterococci } \\
\mathbf{N}=19 \\
\% \\
\end{array}$ & $\begin{array}{c}\text { Other } \\
\mathrm{N}=11 \\
\%\end{array}$ & $\begin{array}{c}\text { Total } \\
\mathbf{N}=126 \\
\%\end{array}$ \\
\hline \multirow{2}{*}{ Potassium iodide $2.0 \%$} & $\mathrm{~S}$ & 88.00 & 86.00 & 79.00 & 100 & 87.30 \\
\hline & $\mathrm{R}$ & 12.00 & 14.00 & 21.00 & 0.0 & 12.70 \\
\hline \multirow{2}{*}{ Calcium hydroxide $2.0 \%$} & $\mathrm{~S}$ & 76.63 & 72.00 & 63.00 & 72.72 & 73.01 \\
\hline & $\mathrm{R}$ & 23.37 & 28.00 & 37.00 & 27.28 & 30.00 \\
\hline \multirow{2}{*}{ Sodium hypochlorite $\mathbf{0 . 5 \%}$} & $\mathrm{S}$ & 56.64 & 53.00 & 42.10 & 6364 & 54.00 \\
\hline & $\mathrm{R}$ & 43.36 & 47.00 & 57.90 & 36.36 & 46.00 \\
\hline \multirow{2}{*}{ Chlorhexidine $1.0 \%$} & $\mathrm{~S}$ & 68.30 & 83.00 & 52.63 & 63.64 & 69.83 \\
\hline & $\mathrm{R}$ & 31.70 & 17.00 & 47.37 & 36.36 & 30.15 \\
\hline
\end{tabular}

Table 3. Phytochemical constituents of Zingiber officinale extract

\begin{tabular}{|l|c|c|}
\hline Chemical tests & Results & Remarks \\
\hline Alkaloid & +ve & Alkaloid present \\
\hline Glycosides & -ve & No glycosides \\
\hline Terpenoid & +ve & Terpenes present \\
\hline Saponins & +ve & Saponins present \\
\hline Flavonoid & +ve & Flavonoid present \\
\hline Tannins & -ve & No tannins \\
\hline Fehling test & -ve & No Reducing sugars \\
\hline
\end{tabular}

\section{Discussion}

Oral diseases sources major health problems in the worldwide [1]. Microorganisms that are able to invade the pulp tissue and survive in a root canal system are the causative pathogens in primary endodontic infections. The bacteria remaining in the root canal system after endodontic treatment cause secondary, or persistent, infections [33] Successful treatment of endodontic infections is strongly dependent on the eradication of microbial infection from the root canal system. Therefore, the absence or presence of bacteria in the root canals prior to obturation is useful information that can help evaluate treatment efficacy [34]. The present study aimed to investigate the bacterial profiles of root canal infection (before and after) filled teeth and susceptibility of bacterial isolates to antibiotics, antimicrobial agents and ginger (Zingiber officinale) extracted. The results of the microbiological analysis of this study revealed that bacteria were found in all infected root canals. Most of the bacterial isolates were isolated belong to $E$. faecalis, Streptococci and anaerobic bacteria. E. faecalis was found most frequently bacterial species before and after filled teeth. This finding agrees to a large extent with the findings of several studies, [35, 36, 37] which found that $E$. faecalis was associated with persistent endodontic infections. This is due to the fact that, Enterococci are able to survive for a long time with a minimum amount of nutrients.[38] In addition E. faecalis has the ability to invade the dentinal tubules, which can allow them to resist the chemomechanical preparation and intracanal medication such as calcium hydroxide [39]. The goal of the treatment of root canal infection is to control the spread of infection and provide symptom relief, which can usually be achieved without the use of antibiotics and other antimicrobial agents. Therefore, all bacterial isolates in this study were tested for susceptibilities to antibiotics, other antimicrobial agent and plant extract with the intention of determining the most effective drug for all bacterial isolated. The result obtained revealed that the most potent antibiotics against all bacterial isolates were found amoxicillin-clavulanic acid and vancomycin, while metronidazole and tetracycline give high resistant ratio. This finding agrees to a large extent with the findings by Endo et al. [40]. Resistance of the bacteria found in endodontic infections to antibiotics has been reported $[12,41]$ The evaluate potency of antimicrobial agents, revealed that, potassium iodide $2 \%$ exhibited most potent activity against bacterial isolates from root canal compare with another antimicrobial agents has been used in this study. Lin et al. was demonstrated that potassium iodide is a better chemical agent for disinfection than calcium hydroxide in shorter exposure times [42]. A clinical study on root-filled teeth with apical periodontitis (failed endodontic cases) demonstrated that a 5 minute final flush with potassium iodide following $2.5 \%$ sodium hypochlorite irrigation completely eradicated bacterial in all [43]. For the prevention of the emergence of resistant microorganisms commonly used plant extracts. The in vitro antibacterial activity of Zingiber officinale was studied against bacterial isolates. The aqueous and ethanolic extracts exhibited antibacterial activity against all bacterial isolates with MIC ranged from 0.5 to 1.3 $\mathrm{mg} / \mathrm{ml}$ and 0.3 to $1.0 \mathrm{mg} / \mathrm{ml}$ respectively. Victor et al., 1996 considered a strong response to exist when the extract produced an effect at concentration of $10 \mathrm{mg} / \mathrm{ml}$ or blow, therefore consider most active extracted from Zingiber officinale [44]. Zingiber officinale extracts has been reported to have antifungal and antibacterial activity in vitro $[45,46]$. These results agree with studies by Gull et al. [47]. The Zingiber officinale extracts having chemical compounds such as saponin, alkaloids and flavonoids have been reported to have antifungal and antibacterial activities in-vitro (Barasch et al [48].

\section{Conclusion}

Based on the study results, amoxicillin-clavulanic acid and vancomycin were the most potent antibiotics and potassium iodide $2 \%$ most antimicrobial agents in vitro, against bacterial sp. isolated from root canal infection, therefore can be used treatment root canal infection. Zingiber officinale extract has potential antimicrobial action against root canal pathogen. Such investigation on natural products to cure diseases may create an alternative source of promising medicines. This study might open the possibilities of finding new clinically effective herbal remedy for root canal infection.

\section{References}

[1] Petersen P. E. International Encyclopedia of Public Health, First Edition (2008). 4. 677-685.

[2] Enzo A. Palombo. Evidence-Based Complementary and Alternative Medicine, Traditional Medicinal Plant Extracts and 
Natural Products with Activity against Oral Bacteria: Potential Application in the Prevention and Treatment of Oral Diseases. Evidence-Based Complementary and Alternative Medicine. (2011). Vol. (2011). 1-15.

[3] Naür R, Sjögren U, Gunthild K, Kahnberg KE, Sundqvist G. Intraradicular bacteria and fungi in root-filled, asymptomatic human teeth with therapy-resistant periapical Lesions: A longterm light and electron microscopic follow-up study. J Endod (1990). 6 (12). 580-588.

[4] Sohansson EU and Sjögren U. Prevalance of black pigmented bacteroides species in root canal infections. J Endod (1989). 15: 13-19.

[5] Siqueira JF J and Roças IN. Exploiting molecular methods to explore endodontic infections: part 2-redefining the endodontic microbiota. J Endod. (2005). 31(7): 488-98.

[6] Bystrom A, Happonen RP, Sjogren U, Sundqvist G. Healing of periapical lesions of pulpless teeth after endodontic treatment with controlled asepsis. Endod Dent Traumatol. (1987). 3(2): 58-63.

[7] Sundqvist G. Taxonomy, ecology, and pathogenicity of the root canal flora. Oral Surg. Oral Med Oral Pathol. (1994). 78: 522-530.

[8] Le Goff A, Bunetel L, Mounton C and Bonnaure-Mallet M. Evaluation of root canal bacteria and their antimicrobial susceptibility in teeth with necrotic pulp. Oral Microbiol. Immunol. (1997). 12: 318-322.

[9] Baumgartner JC and Falkler WA. Bacteria in the apical $5 \mathrm{~mm}$ of infected root canals. Journal of Endodontics. (1991). 17: 380-383.

[10] Hancock HH, Sigurdsson A, Trope M and Moiseiwitsch J. Bacteria isolated after unsuccessful endodontic treatment in a North American population. Oral Surgery, Oral Medicine, Oral Pathology, Oral Radiology, and Endodontics. (2001). 91, 579-86.

[11] Pinheiro ET, Gomes BPHA, Ferraz CCR, Sousa ELR, Teixeira FB and Souza-Filho FJ. Microorganisms from canals of root-filled teeth with periapical lesions. International Endo- dontic Journal. (2003). 36: 1-11.

[12] Baumgartner JC. Antibiotics in endodontic therapy. In: Newman MG, Van Winkelhoff AJ, eds. Antibiotics and antimicrobial use in dental practice. 2nd ed. Carol Stream, IL: Quintessence Publishing Co, Inc. (2001). 143-57.

[13] Moller AJR. Microbial examination of root canals and periapical tissues of human teeth. Odontologisk Tidskrift (1966). 74: 1-380.

[14] Reit C and Dahlen G. Decision strategies in endodontics: on the design of a recall programmed. Endodontics and Dental Traumatology (1988). 3: 233-239.

[15] Drucker DB and Melville TH. The classification of some oral streptococci of human or rat origin. Archives of Oral Biology (1971). 16: 845-53.

[16] McComb D and Smith DC. A preliminary scanning microscopic study of the Root canals after endodontic procedures. Journal of Endodontics. (1975). 1: 238-42.

[17] Spangberg L. Instruments materials and devices. In: Cohen S, Burns RC, eds. Pathways of the Pulp, 8th ed. St Louis, MO, USA: Mosby Inc. (2002). 521-72.

[18] Jeansonne MJ and White RR. A comparison of $2.0 \%$ chlorhexidine gluconate and $5.25 \%$ sodium hypochlorite as antibacterial endodontic irrigants. Journal of Endodontics. (1994). 20: 276-8.

[19] Buck RA, Eleazer PD, Staat RH and Scheetz JP. Effectiveness of three endodontic Irrigants at various tubular depths in human dentin. Journal of Endodontics. (2001). 27: 206-8.

[20] Barnhart BD, Chuang A, Lucca JJ, Roberts S, Liewehr F and Joyce AP. An in vitro evaluation of the cytotoxicity of various endodontic irrigants on human gingival fibroblasts. J Endod (2005). 31: 613-615.

[21] Spangberg L, Engström B and Langeland K. Biologic effects of dental materials. 3. Toxicity and antimicrobial effect of endodontic antiseptics in vitro. Oral Surg Oral Med Oral Pathol. (1973). 36: 856-871.

[22] Orstavik D and Haapasalo M. Disinfection by endodontic irrigants and dressings Of experimentally infected dentinal tubules. Endod Dent Traumatol. (1990) 6: 142-9.

[23] Estrela C, Holland R, Bernabé PFE, ]ouza V and Estrela CRA. Antimicrobial potential of medicaments used in healing process in dog's teeth with apical periodontitis. Braz Dent J. (2004). 15: 1815 .

[24] Sirén EK, Haapasalo MP, Waltimo TM and Ørstavik D. In vitro antibacterial Effect of calcium hydroxide combined with chlorhexidine or iodine potassium iodide on Enterococcus faecalis. Eur. J. Oral Sci. (2004) 112, 3263-31.
[25] Muhsin D A and Hussein F M. The Antibacterial Effect of Ginger and Garlic Extracts on Some Pathogenic Bacteria Isolated from Patients with Otitis Media. (2014). 2(5): 1-5.

[26] Cheesbrough, M. District Laboratory Practice in Tropical Country (PT 2). University Press, Cambridge. (2000). 157-255.

[27] Slots, J and Taubman, M.A. Contemporary Oral Microbiology and Immunology. Mosby Year Book, St. Louis. (1992).

[28] Alfred E. B. B. Microbiological Applications Lab Manual, Eighth Edition The McGraw-Hill Companies, (2001).

[29] Clinical and Laboratory Standards Institute. Performance standard for antimicrobial susceptibility testing. Approved standard M100S20-30(1). National Committee for Clinical Laboratory Standards, 2010, Wayne, PA. USA.

[30] Kirby-Bauer A: Antimicrobial sensitivity testing by agar diffusion method. J Clin Pathol. (1996). 44: 493.

[31] Natta L, Orapin K, Krittika N and Pantip B: Essential oil from five Zingiberaceae for anti-food-borne bacteria. Int Food Res J. (2008). 15: 337-346.

[32] Jadon R and Dixit S. Phytochemical extraction and antimicrobial activity of some medicinal plants on different microbial strains. Journal of Medicinal Plants Studies. (2014). (2) 3: 58-63.

[33] Dahlen G. Culture-based analysis of endodontic infections. In: Fouad AF, ed. Endodontic microbiology. 1st ed. Ames, IA: WileyBlackwell. (2009). 225-241.

[34] Abbaszadegan A, Akbar K and Mohammad M. Comparison of Antimicrobial Efficacy of IKI and $\mathrm{NaOCl}$ Irrigants in Infected Root Canals: An In Vivo Study. I E J. (2010). (5)3: 102-106.

[35] Schirrmeister JF, Liebenow AL, Braun G, Wittmer A, Hellwig E and Al-Ahmad A. Detection and eradication of microorganisms in root-filled teeth associated with periradicular lesions: An in vivo study. J Endod. (2007). 33: 536-340.

[36] Roca's IN, Jung IY, Lee CY and Siqueira JF. Polymerase chain reaction identification of microorganisms in previously root-filled teeth in a South Korean population. J. Endod. (2004). 30: 504-508.

[37] Al-Samahi S and Al-Omari M. A. Detection of bacteria in endodontic samples and its association with defined clinical signs and symptoms of endodontic infection S. J. Oral Sci. (2014). (1) 2: 83-89.

[38] Figdor D, Davies JK and Sundqvist G. Starvation survival, growth and recovery of Enterococcus faecalis in human serum. Oral Microbiol Immunol. (2003). 18: 234-239.

[39] Haapasalo M and Orstavik D. In vitro infection and disinfection of dentinal tubules. J Dent Res. (1987). 66: 1375-1379.

[40] Endo M. S, Signorett F. G. C, Kitayama V. S, Marinho A. C. S Martinho, F. C. and Gomes B. P C. Culture and molecular detection of Enterococcus faecalis from patients with failure endodontic treatment antimicrobial susceptibility of clinical isolates. Braz Dent Sci. (2014). 17(3): 83-91.

[41] Baumgartner JC and Xia T. Antibiotic susceptibility of bacteria associated with endodontic abscesses. J Endod.( 2003). 29: 44-47.

[42] Lin S, Kfir A, Laviv A, Sela G and Fuss Z. The in vitro antibacterial effect of iodine-potassium iodide and calcium hydroxide in infected dentinal tubules at different time intervals. J Contemp Dent Pract. (2009). 10: 59-66.

[43] Peciuliene V, Reynaud AH, Balciuniene I and Haapasalo M. Isolation of yeasts and enteric bacteria in root-filled teeth with chronic apical periodontitis. Int. Endod. J. (2001). 34: 429-434.

[44] Victor N., Gaberiela R. and Xavier L. antimicrobial evaluation of some plants used in Mexican traditional medicine for the treatment of infectious diseases. Journal of Ethnopharmacology. (1996). 53: 143-147.

[45] Sovova M and Sova P. Pharmaceutical importance of Allium sativum L.5. Hypolipemic effects in vitro and in vivo, Ceska Slov Farm53 (2004). 117-123 (in Czech).

[46] Durairaj S. and Srinivasan, S. P. Lakshmanaperumalsamy, In vitro antibacterial activity and stability of garlic extract at different $\mathrm{pH}$ and temperature, Electronic J. Biol. (2009). 5: 5-10.

[47] Gull I, Saeed M, Shaukat H, Aslam S. M, Samra Z. Q and Athar A. M. Inhibitory effect of Allium sativum and Zingiber officinale extracts on clinically important drug resistant pathogenic bacteria. Annals of Clinical Microbiology and Antimicrobials. (2012). 11: 8 1-6.

[48] Barasch A, Safford M.M, Dapkute-Marcus I and Fine D.H. Efficacy of chlorhexidine gluconate rinse for treatment and prevention of oral candidiasis in HIV-infected children: a pilot study. Oral Surg. Oral Med. Oral Pathol. Oral Radiol. Endod. (2004). (97) 2: 204-207. 